\title{
Environmental Implications of Mining of Beach Placers for Heavy Minerals
}

\author{
Debashish Sengupta and Shayantani Ghosal* \\ Department of Geology and Geophysics, IIT Kharagpur, India
}

Submission:March 08, 2017; Published: May 02, 2017

*Corresponding author: : Shayantani Ghosal, Department of Geology and Geophysics, IIT Kharagpur Campus, West Bengal 721302, India, Email: 114shg@gmail.com

\section{Abstract}

With the increasing demand for clean energy in emerging economies like India, the requirement for Rare Earth Elements (REE) along with thorium is getting enhanced. In such a situation an indigenous resource of these are important. The easy extraction of these elements from beach placers has attracted considerable interest. However, mining in beach areas can have a detrimental impact, if suitable measures are not undertaken. The impact of mining of heavy minerals, primarily by dredging, along the east coast of India is discussed.

Keywords: Heavy minerals; Rare earth metals; Monazites; Erosion; Beach placers

\section{Introduction}

The peninsular India is bounded on three sides by water and one side by land. It has a long coastal tract of 7,517km. The sedimentary deposit present along this vast coast is an important setting for mineral deposits. The placer deposit of the state of Kerala and Odisha is a major source of heavy mineral deposits [1]. The mining and processing of heavy minerals from beach sands in coastal areas like in India entails specifically those associated with beach erosion, receding of the shore lines and the environmental impact.

The case study is typically the Odisha- Andhra Pradesh Coastal Placers [2], covering more than $400 \mathrm{~km}$ which are enriched in minerals like Monazite, Zircons and Xenotime. These placers are beneficial for the extraction of Rare Earth Elements (REE), apart from ilmenite and rutile for various applications including sensors and smart phones respectively [3]. The Indian Rare Earths Limited has recently signed a joint venture agreement with Toyota Tshusho Corporation to supply Monazites to Japan for extraction of Rare-Earths, primarily the Light Rare Earth metals [4]. Considering these aspects the mining of these heavy mineral beach placers of East Coast of India is not only a lucrative project, but also important to strengthen the strategic mineral reserve of the country. REE's with its various uses in green technology and electronics like wind turbines and Neodymium magnets respectively is quickly acquiring the position of strategic minerals if not officially then certainly in its usefulness [3].

\section{Discussion}

Extensive studies undertaken [5] indicate that mining of beach sands using dredging operations affect the fragile coastal dunes as well as the sand bars/shoal, which leads to further receding shorelines. The study area mostly has high energy waves which result in constant washing away of sediments thus creating an unbalanced situation, in such condition dredging of dunes and berms can aggravate the condition of erosion, thus creating a condition of imbalance between erosion and accumulation of sedments. The constant disturbance of palaeodunes disturbs the natural barrier which helped in creating a hindrance for beach erosion. The area also experiences major storm surges every year which further aggravate the disproportion of sedimentary condition of the area.

The area around Rushikulya river mouth also comprises of the Oliver ridley turtle nesting grounds in Odisha [6] as well as the horseshoe crab habitats. Both these organisms are rare and extremely susceptible to the changes of the environment of its nesting. The organisms primarily depend upon the size of the particles over which they lay their eggs. The horse shoe crabs favours sediment sizes ranging between 2.8-2.46phi, any change in this range and they shift their nesting ground [7]. The turtles also show a similar breeding pattern, Figure 1 shows their nesting areas. Apparently the constant mining and 
dredging activities disturbs the sediment size distribution, hence disrupting their normal turtle nesting environment. This results in further decrease in the number of these rare marine species.

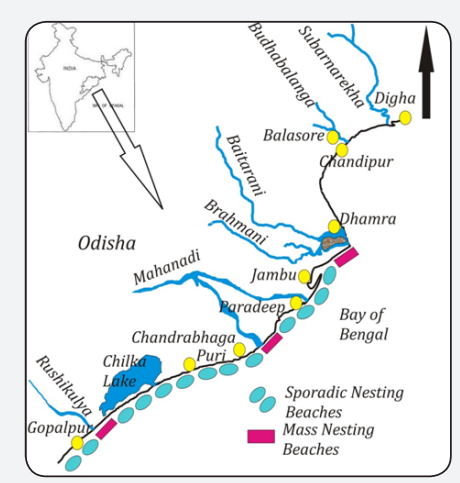

Figure1: Map showing the coastal areas of Odisha and the location of the nesting areas of Oliver ridley turtle and horseshoe crabs (modified after B. Pandav et. al., 2006).

The receding coastline can be averted with the help of plantation of vegetation which are capable of acting as effective barrier for storm surges and the high energy beach environment [8]. These transplantations is undertaken to restore soil micro fauna to the disturbed beach deposits. Dune vegetation is effected by geology of the area, and has more than 163 species of flora in east coast itself. The constant anthropogenic activity poses a threat to the local vegetation resulting in changing landforms. The coastal vegetation is a potential agent which holds the soil together and prevents the retreat of shore line. In general, due attention needs to be paid to have optimal similarity between post-mining and pre-mining flora, thereby limiting any comprehensible decline in natural/indigenous plant species [9].

India has one of the largest Thorium reserves of the world [10]. The east coast placer of India contains along with heavy minerals radioactive elements mostly Uranium, Thorium and Potassium also. Of these they have a pretty high concentration of ${ }^{232} \mathrm{Th}$. A quantitative estimation of concentration of thorium is present for areas close to Gopalpur and the Rushikulya river mouth (Figure 1). For areas close to Gopalpur, namely the Garampeta and Markandi beach area, the thorium concentration ranges between $394-4521$ with a mean of $2489 \mathrm{~Bq} \mathrm{~kg}^{-1}$ [11]. Close to the Rushikulya river mouth the concentration of Thorium varies from 40- 5740Bq kg-1 and on an average $1670 \mathrm{~Bq} \mathrm{~kg}^{-1}$ [12]. It has also been shown that Monazite, a Rare Earth Phosphate tends to get preferentially enhanced in airborne dust being softer than the titanium and zirconium bearing minerals [13]. The focus of our discussion will now shift from the effects of man made activities on the environment to the effect of the ambient environment on the human health due to change in NORM. The workers working in the mines to extract various heavy minerals are in constant contact of radioactive elements primarily through inhalation. The only way to cope with such an incident is to put a limit upto which a mine worker can be exposed to radioactivity. In Australia that limit is $>1 \mathrm{mSv}^{-1}[4]$.

\section{Conclusion}

Typical remediation methodology to be adopted should be preferably based on mobile mining which will help in subsequent decrease of mining foot print and plantation of local and indigenous species.

\section{References}

1. (2011) An overview of Rare Earth Elements, The Centre for Techno Economic Mineral policy Options (C-TEMPO), Ministry of Mines, Government of India, India.

2. Sengupta D, Van Gosen BS (2016) Placer-Type Rare Earth Element Deposits. Society of Economic Geologists, Reviews in Economic Geology 18: 81-100.

3. Alonso E, Sherman AM, Wallington TJ, Everson MP, Field FR, et al (2012) Evaluating Rare Earth Element Availability: A Case with Revolutionary Demand from Clean Technologies. Environ Sci Technol 46(6): 3406-3414.

4. Miranda KR, Bertil G, Anne K, Esa P, Paloma M, et al. (2015) Past experience of environmental health and safety issues in REE mining and processing industries and an evaluation of related $\mathrm{Eu}$ and international standards and regulations. Eu Rare $7^{\text {th }}$ framework programme, Europe.

5. Bird E, Lewis N (2014) Beach Renourishment. Springer Briefs in Earth Sciences, pp. 7-28.

6. Pandav B, Choudhury BC, Kar CS (2006) Sea turtle nesting habitats on the coast of Orissa. Marine turtles of the Indian subcontinent 1: 88.

7. Chatterji A, Abidi SAH (1993) The Indian horse shoe crab- a living fossil. Journal of Indian Ocean Studies 1: 43-48.

8. Rodrigues RS, Mascarenhas A, Jagtap TG (2011) An evaluation of flora from coastal sand dunes of India: Rationale for conservation and management. Ocean \& Coastal Management 54(2): 181-188.

9. Lloyd MV, Barnett G, Doherty MD, Jeffree RA, John J, et al. (2002) Managing the impacts of the Australian minerals industry on biodiversity- Final Report. Australian centre for Mining Environmental Research, Brisbane, Australia.

10. IAEA (2005) Thorium Fuel Cycle -Potential Benefits and Challenges. Vienna, Austria.

11. Ghosal S, Agrahari S, Guin R, Sengupta D (2017) Implications of modelled radioactivity measurements along coastal Odisha, Eastern India for heavy mineral resources. Estuarine, Coastal and Shelf Science 184: 83-89.

12. Rao NS, Sengupta D, Guin R, Saha SK (2009) Natural radioactivity measurements in beach sand along southern coast of Orissa, eastern India. Environ Earth Sci 59(3): 593-601.

13. Hewson GS (1997) Inhalation and retention of thorium dusts by mineral sands workers. Ann occup Hyg 41(Suppl 1): 92-98. 


\section{Your next submission with Juniper Publishers} will reach you the below assets

- Quality Editorial service

- Swift Peer Review

- Reprints availability

- E-prints Service

- Manuscript Podcast for convenient understanding

- Global attainment for your research

- Manuscript accessibility in different formats

( Pdf, E-pub, Full Text, Audio)

- Unceasing customer service

Track the below URL for one-step submission https://juniperpublishers.com/online-submission.php 